\title{
Comparative evaluation of polymerase chain reaction assay with microscopy for detection of asymptomatic carrier state of theileriosis in a herd of crossbred cattle
}

\author{
Gaurav Charaya ${ }^{1}$, N. K. Rakha ${ }^{1}$, Sushila Maan ${ }^{2}$, Aman Kumar ${ }^{2}$, Tarun Kumar $^{3}$ and Ricky Jhambh ${ }^{1}$
}

1. Department of Veterinary Medicine, Lala Lajpat Rai University of Veterinary and Animal Sciences, Hisar, Haryana, India; 2. Department of Animal Biotechnology, Lala Lajpat Rai University of Veterinary and Animal Sciences, Hisar, Haryana, India; 3. Teaching Veterinary Clinical Complex, Lala Lajpat Rai University of Veterinary and Animal Sciences, Hisar, Haryana, India.

Corresponding author: N. K. Rakha, e-mail: drrakha@gmail.com,

GC: gcharaya9@gmail.com, SM: sushilamaan105@gmail.com, AK: aman.abt@luvas.edu.in, TK: tarunvet@gmail.com, RJ: jhambricky@gmail.com

Received: 05-05-2016, Accepted: 18-08-2016, Published online: 30-09-2016

doi: 10.14202/vetworld.2016.1039-1042 How to cite this article: Charaya G, Rakha NK, Maan S, Kumar A, KumarT, Jhambh R (2016) Comparative evaluation of polymerase chain reaction assay with microscopy for detection of asymptomatic carrier state of theileriosis in a herd of crossbred cattle, Veterinary World, 9(9): 1039-1042.

\begin{abstract}
Aim: This study aims to develop and to standardize a polymerase chain reaction (PCR) assay that will diagnose clinical as well as carrier state of the disease and to compare the results with conventional microscopy technique.

Materials and Methods: A herd of crossbred cattle with the previous history of theileriosis in village Lahli, district Rohtak, Haryana, was selected for this study. A total of 29 blood samples were collected randomly from cows including five clinically ill cattle. Blood smears from all animals and lymph node biopsy smears from animal with swollen lymph nodes were examined microscopically after conventional Giemsa staining. Phenol chloroform isoamyl alcohol method was used for extracting DNA from blood. Previously published primers targeting cytochrome $b$ gene sequence of Theileria annulata were used in the PCR assay that was standardized to use in the laboratory.
\end{abstract}

Results: Out of 29 samples tested,18 (62.06\%) were found positive for theileriosis by PCR assay, whereas only 10 (34.48\%) samples were detected positive by conventional microscopic technique using Giemsa staining method.

Conclusions: On the basis results of comparative studies, it can be concluded that PCR assay is a more sensitive than microscopic examination for detection of theileriosis. This can be attributed to the ability of PCR assay to detect small amounts of genomic DNA of T. annulata or low parasitemia in cows. Therefore, PCR assay can serve as a more sensitive tool to detect Theileria for detection of theileriosis even in asymptomatic carrier cattle which is important for the implementation of successful control programs.

Keywords: Carrier state, cytochrome b, Giemsa staining, polymerase chain reaction assay, theileriosis, Theileria annulata.

\section{Introduction}

In India, bovine tropical theileriosis is an important endemic hemoprotozoan disease caused by Theileria annulata. The disease is characterized by a marked rise in body temperature, reaching $40-41.5^{\circ} \mathrm{C}$, depression, lacrimation, nasal discharge, swelling of the superficial lymph nodes, and anemia. It is transmitted by Hyalomma anatolicum, a three host tick which act as a biological vector for $T$. annulata. Recovered cows from acute or primary theileriosis, remain infected for a long period and even for the rest of their lives, acting as reservoirs of infection for ticks which cause natural transmission of the disease $[1,2]$.

The conventional method for identification of organism includes an examination of blood smears

Copyright: Charaya, et al. Open Access. This article is distributed under the terms of the Creative Commons Attribution 4.0 International License (http://creativecommons.org/licenses/ by/4.0/), which permits unrestricted use, distribution, and reproduction in any medium, provided you give appropriate credit to the original author(s) and the source, provide a link to the Creative Commons license, and indicate if changes were made. The Creative Commons Public Domain Dedication waiver (http:// creativecommons.org/publicdomain/zero/1.0/) applies to the data made available in this article, unless otherwise stated. using Giemsa staining. Indeed, Giemsa-stained blood smears can be used as a suitable method to detect Theileria in the animals suspected to be suffering from clinically acute theileriosis, but it is not applicable for the detection of presymptomatic or carrier animals, where parasitemia is very low [3]. Identification of such animals is, therefore, crucial for the accurate assessment of epidemiology of the disease and the implementation of control programs aimed at improving productivity.

Molecular methods, with a high degree of sensitivity and specificity, have been developed to identify various Theileria species in persistently infected cattle [4]. Therefore, this study was planned to standardize the polymerase chain reaction (PCR) assay for detection of $T$. annulata - infected asymptomatic carrier animals and to compare PCR assay with microscopic examination.

\section{Materials and Methods}

\section{Ethical approval}

Samples were collected by qualified veterinarians as per standard sample collection method without 
any stress/harm to animals and with due permission of the Institutional Animal Ethics Committee.

\section{Sample collection}

Crossbred cattle herd with a recent history of three clinical cases of theileriosis detected microscopically was selected for sampling. A total of 29 blood samples ( $10 \%$ approximately) from a herd of 250 cattle comprising 67 calves and 183 adult animals were collected by random sampling including five clinically ill cattle in vials containing ethylene diamine tetra acetic acid. The clinically affected animal was having a fever, pale mucous membrane, and swollen lymph nodes. Thin blood smears were prepared from each sample at the site of sample collection and fixed using methanol and remaining part of the sample was brought to the laboratory for DNA extraction. Lymph node biopsy was also taken from four animals having swollen pre-scapular lymph nodes, and a smear was made and fixed in methanol at the site of sample collection.

\section{Clinical observations and history taking}

Age, sex, lymph node examination, mucous membrane examination, and rectal temperature of all 29 animals included in the study were recorded.

\section{Microscopic examination}

Fixed thin blood smear and lymph node biopsy smears were stained with Giemsa stain for $30 \mathrm{~min}$ [5]. Blood smears were examined for intra erythrocytic forms (signet ring, dot, orcomma shaped) of T. annulata piroplasm under $100 \times$ objective magnifications. About 20 microscopic fields, per slide, were observed to view the parasite. The presence of single piroplasms was recorded as positive for T. annulata. Fixed lymph node biopsy smears were examined under $100 \times$ magnifications in the search for characteristic Koch blue bodies, the presence of which is confirmatory diagnosis of theileriosis.

\section{DNA extraction}

DNA was extracted using phenol-chloroform isoamyl alcohol method. To $500 \mu 1$ of whole blood three volume of red blood cell lysis buffer was added and kept for $15 \mathrm{~min}$ at $37^{\circ} \mathrm{C}$. To this $600 \mu \mathrm{l}$ of DNA extraction buffer was added followed by $10 \%$ sodium dodecyl sulfate $(260 \mu \mathrm{l})$. Proteinase K $(20 \mu \mathrm{l})$ was added and the sample was incubated at $50^{\circ} \mathrm{C}$ for $1 \mathrm{~h}$. After $1 \mathrm{~h}$ of incubation, an equal volume of saturated phenol was added and kept for $15 \mathrm{~min}$ at $37^{\circ} \mathrm{C}$. Centrifugation at $12,000 \mathrm{rpm}$ was done and upper aqueous phase was separated. To aqueous phase, the equal volume of phenol-chloroform isoamyl alcohol was added and centrifuged at $12000 \mathrm{rpm}$ for $15 \mathrm{~min}$. Upper aqueous phase was separated in a fresh Eppendorf and to it, chloroform isoamyl alcohol was added in equal volume, mixed and centrifuged at 12,000 rpm for $15 \mathrm{~min}$. To aqueous phase $1 / 10^{\text {th }}$ volume of $3 \mathrm{M}$ sodium acetate and three volumes of chilled absolute ethanol was added and incubated overnight at $4^{\circ} \mathrm{C}$. Precipitate was obtained by centrifugation at $12,000 \mathrm{rpm}$ for $20 \mathrm{~min}$.
The precipitate was washed with $1 \mathrm{ml}$ of $70 \%$ ethanol and centrifuged at 12,000 rpm for $10 \mathrm{~min}$. The pellet was air dried and dissolved in $50 \mu 1$ of nuclease free water and stored at $-20^{\circ} \mathrm{C}$ for further use.

\section{PCR assay}

Cytochrome b gene of T. annulata was targeted for its detection and identification. A primer set (Forward: 5'-ACT TTG GCC GTA ATG TTA AAC-3'/Reverse: 5'-CTC TGG ACC AAC TGT TTG G-3') was used for amplification which was earlier reported by Bilgic et al. [6]. PCR assay was carried out in $200 \mu 1$ PCR tubes using $\mathrm{ABI}$ thermocycler. Each $12.5 \mu 1$ reaction mixture comprised $2 \mu \mathrm{l}$ of template DNA, $6.25 \mu \mathrm{l}$ Dream Taq Green PCR Master Mix $(\times 2)$ (Fermentas), $0.5 \mu 1$ of each cytob1 primer set (forward and reverse primer), and $3.25 \mu 1$ nuclease free water. The PCR conditions includes initial denaturation at $95^{\circ} \mathrm{C}$ for $2 \mathrm{~min}$; followed by 30 cycles of $95^{\circ} \mathrm{C}$ for $30 \mathrm{~s}$ (denaturation), $60^{\circ} \mathrm{C}$ for $30 \mathrm{~s}$ (annealing), and $72^{\circ} \mathrm{C}$ for $1 \mathrm{~min}$ (extension); with a final extension step of $72^{\circ} \mathrm{C}$ for $10 \mathrm{~min}$. $5 \mu \mathrm{l}$ of amplified PCR product mixed with $6 \mathrm{x}$ loading dye was loaded for electrophoresis in 1.5\% agarose gel along with $100 \mathrm{bp}$ DNA ladder. The images were captured and documented using gel documentation system (Bio Rad., USA).

\section{Results}

Out of 29 samples, 10 (34.48\%) samples were found positive in Giemsa's stained blood smears showing characteristic shaped piroplasm (Figure-1), whereas $18(62.06 \%)$ were found positive for theileriosis by PCR assay (Table-1). Gel electrophoresis of PCR products showed specific amplicon of $312 \mathrm{bp}$ (Figure-2). The samples found negative with PCR assay were also found to be negative on blood smear examination. Koch's blue bodies were seen in biopsy made from swollen lymph nodes of all four cows (Figure-3). On clinical examination, the increase in rectal temperature was seen in 5(17.24\%) and swollen lymph nodes in $4(13.79 \%)$ animals out of 29

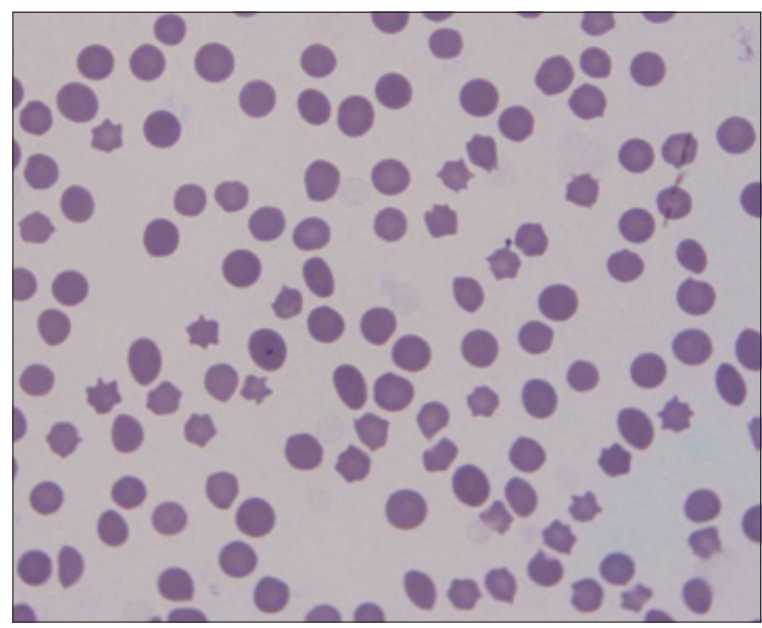

Figure-1: Signet ring intra erythrocytic piroplasm situated on or near the margin of the erythrocytes. 
Table-1: Comparison of microscopy and PCR assay for detection of T.annulata in terms of prevalence.

\begin{tabular}{lccccc}
\hline Diagnostic test & \multicolumn{2}{c}{ Sample tested } & Positive & Prevalence(\%) \\
\cline { 2 - 5 } & Symptomatic animals & Asymptomatic animals & & \\
\hline Microscopy & 5 & 24 & 10 & 34.48 \\
PCR & 5 & 24 & 18 & 62.06 \\
\hline
\end{tabular}

T. annulata=Theileria annulata, $\mathrm{PCR}=$ Polymerase chain reaction

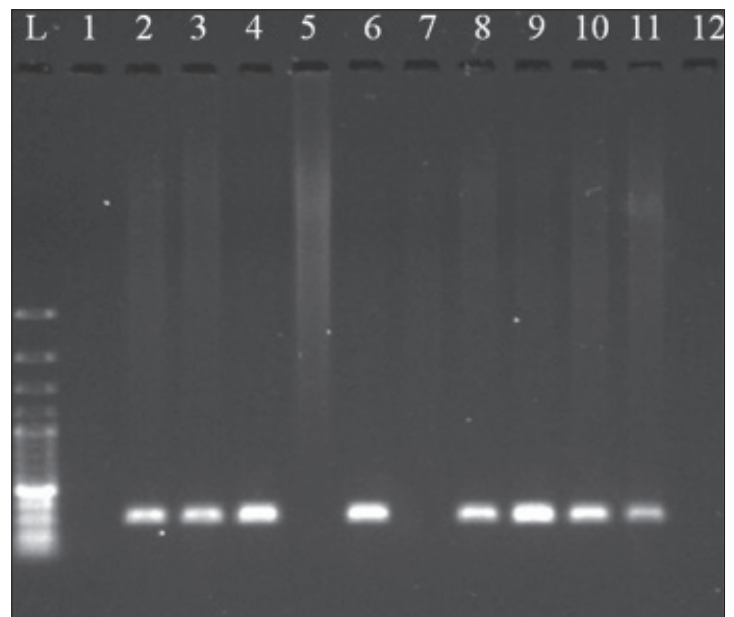

Figure-2: Gel electrophoresis results of polymerase chain reaction products showing specific amplification of 312 bp. L-Ladder 100bp; 1- Control negative; 2- Control positive; 3-12- Test samples; 5,7 and 12- Negative; $3,4,6,8,9,10,11$-Positive.

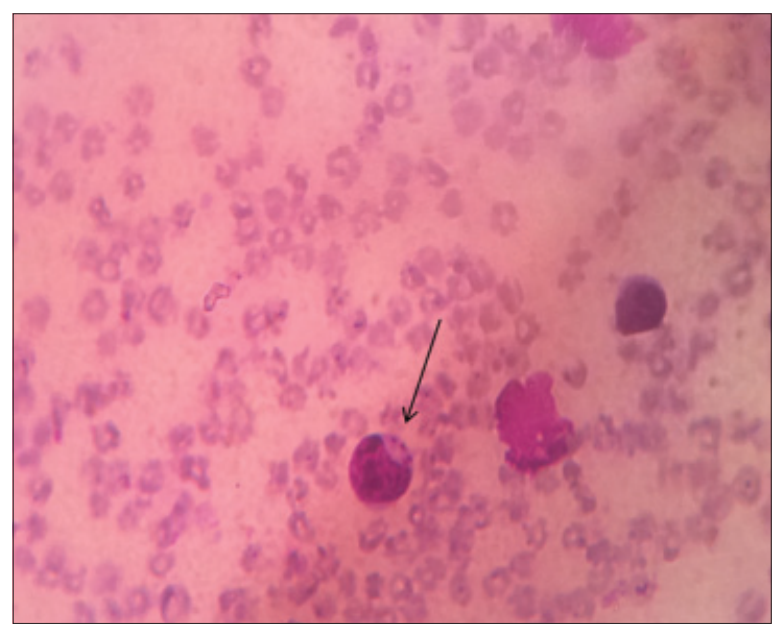

Figure-3: Koch's blue bodies (macroschizont stage) in lymphocyte in Giemsa stained lymph node biopsy smear.

screened.Five animals showing fever were diagnosed positive for theileriosis using microscopic examination as well as PCR assay. However, $13(72.22 \%)$ out of 18 animals diagnosed positive by PCR assay were asymptomatic carrier for theileriosis. Among 18 positive cases, 16 were adult whereas only 2 calves were found affected. PCR assay was negative on blood samples of cattle infected with Babesia bigemina and Trypanosoma evansi.

\section{Discussion}

T. annulata is one of the most prevalent intra erythrocytic hemoprotozoan affecting crossbred cattle in India. Identification of carrier cattle is important as they are main source for the maintenance and perpetuation of Theileria in the environment and plays an important role in control program for theileriosis. Cattle become carriers when they survive the acute phase of the disease. After recovery, a low number of $T$. annulata piroplasms still remains in the body. In the most laboratories, detection of theileriosis is done by examining 50 microscopic fields for detection of parasites in blood smears which is a specific diagnosis but lacks sensitivity. In spite of the fact that method being cheaper, quicker, and easier to perform still requires high parasitemia, good smear preparation, proper staining and a well-trained microscopist. Although microscopic examination remains the convenient technique for day-to-day diagnosis of clinical cases, yet it is not able to detect carrier cattle due to the very low numbers $\left(10^{-3} \times 5 \times 10^{-1}\right)$ of infected erythrocytes [7].

PCR is now routinely used around the world for investigations of Theileria infections, particularly to determine carrier animals $[6,8]$. The forward and reverse primers used in this study were previously designed as a $T$. annulata species-specific primer based on cytochrome $b$ genesequences for the detection of this parasite in the carrier animals [5].

In this study, the prevalence of theileriosis was found to be $62.06 \%$ using PCR assay, whereas only $34.48 \%$ using microscopy which clearly indicates that PCR assay is the more sensitive tool in diagnosing theileriosis. It has been revealed that microscopic examination is a less sensitive method which has also been reported by other workers [9-15]. However, both microscopy and PCR assay were found to be $100 \%$ specific in the diagnosis of theileriosis. PCR assay showed no cross-reactivity with Babesia sp. and Trypanosoma sp. and can be used specifically to diagnose theileriosis in herd and differentiate it from other hemoprotozoan diseases.

By relating clinical findings with results from conventional staining and PCR assay, it has been revealed that a large section of screened herd is asymptomatic carrier.

\section{Conclusions}

From this study, it can be concluded that detection of asymptomatic carrier state is difficult to diagnose by conventional staining, whereas PCR assay can precisely determine the carrier state. Results received from PCR assay will certainly help in planning control programs. 


\section{Authors' Contributions}

GC and NKR designed and planned the study. $\mathrm{GC}$ and NKR collected the samples and prepared the onsite smears slides. SM, AK, and GC performed biotechnological part of the study. NKR, TK, and RJ examined the stained smear. GC and AK drafted the manuscript. SM critically reviewed the manuscript. All authors read and approved the final manuscript. NKR finalized the manuscript and sent for publication.

\section{Acknowledgments}

The authors acknowledged Dr. Gulshan Narang, Professor, Department of Veterinary Public Health and Epidemiology, College of Veterinary Sciences, LUVAS for his valuable help in conduct of this study. Funds and facilities of department were utilized for conducting present study.

\section{Competing Interests} interests.

The authors declare that they have no competing

\section{References}

1. Cacci, S., Camma, C., Onuma, M. and Severini, C. (2000) The b-tubulin gene of Babesia and Theileria parasites is an informative marker for species discrimination. Int. J.Parasitol., 30:1181-1185.

2. Kirvar, E., Ilhan, T., Katzer, F., Hooshmand-Rad, E., Zweygarth, C., Gerstenberg, P.P. and Brown, C.G. (2000) Detection of Theileria annulata in cattle and vector ticks by PCR. Parasitology, 120(3): 245-254.

3. Friedhoff, K. and Bose, R. (1994) Recent developments in diagnostics of some tick-borne diseases. In: Uilenberg, G., Permin, A. and Hansen, J.W., editors. Use of Applicable Biotechnological Methods for Diagnosing Haemoparasites. Proceedings of the Expert Consultation, Merida, Mexico, Food and Agriculture Organisation of the United Nations (FAO), Rome, Italy.p46-57.

4. Altay, K., Aydın, M.F., Dumanli, N. andAktas, M. (2008) Molecular detection of Theileria and Babesia infections in cattle. Vet.Parasitol., 158:295-301.

5. Benjamin, M. (1978) Outline of Veterinary Clinical Pathology. $3^{\text {rd }}$ ed. The Iowa State University, Press, Ames, Iowa, U.S.A. p51-53.

6. Bilgic, H.B., Karagenc, T., Shiels, B., Tait, A., Eren, H. and Weir, W. (2010) Evaluation of cytochrome b as a sensitive target for PCR based detection of T. annulata carrier animals. Vet. Parasitol., 174: 341-347.

7. Salih, D.A., Hassan, S.M. and El Hussein, A.M. (2007) Comparisons among two serological tests and microscopic examination for the detection of Theileria annulata cattle in Northern Sudan. Prev. Vet. Med., 81:323-326.

8. Shayan, P. and Rahbari, S. (2005) Simultaneous differentiation between Theileria sp. and Babesia sp. on stained blood smear using PCR. Parasitol. Res., 97:281-286.

9. Noaman, V. (2014) Comparison of molecular and microscopic technique for detection of Theileria spp. in carrier cattle. J. Parasit. Dis., 38(1): 64-67.

10. Nayel, M., El-Dakhly, K.M., Aboulaila, M., Elsify, A., Hassan, H., Ibrahim, E., Salama, A. and Yanai, T. (2012) The use of different diagnostic tools for Babesia and Theileria parasites in cattle in Menoufia, Egypt. Parasitol. Res., 111(3):1019-1024.

11. Hoghooghi-Rad, N., Ghaemi, P. and Shayan, P. (2011) Detection of native carrier cattle infected with Theileria annulata by seminested PCR and smear method in Golestan province of Iran. World Appl. Sci. J., 12(3): 317-323.

12. Chauhan, H.C., Patel, B.K., Bhagat, A.G., Patel, M.V., Patel, S.I., Raval, S.H., Panchasara, H.H., Shrimali, M.D., Patel, A.C. and Chandel, B.S. (2015) Comparison of molecular and microscopic technique for detection of Theileria annulata from the field cases of cattle.Vet. World, 8(11): 1370-1374

13. Roy, K.C., Ray, D., Bansal, G.C. and Singh, R.K. (2000) Detection of Theileria annulata carrier cattle by PCR. Indian J. Exp. Biol., 38: 283-284.

14. Kohli, S., Atheya, U.K. and Thapliyal, A. (2014) Prevalence of theileriosis in cross-bred cattle: Its detection through blood smear examination and polymerase chain reaction in Dehradun district, Uttarakhand, India. Vet. World, 7(3): 168-171.

15. Azizi, H., Shiran, B., Farzaneh, D.A., Salehi, F. and Taghadosi, C. (2008) Detection of Theileria annulata by PCR and its comparison with smear method in native carrier cows. Biotechnology, 79(3): 574-577. 